\title{
Land Evaluation of Kabirabad 2 Micro-Watershed in Northern Eastern Transition Zone of Karnataka, India
}

\author{
N.V. Manjunath ${ }^{1}{ }^{*}$, Ashok S. Alur ${ }^{1}$, B.V. Shreenivas ${ }^{2}$, P.K. Naikodi ${ }^{2}$ and M. Shivanna ${ }^{1}$ \\ ${ }^{1}$ Department of Soil Science and Agricultural Chemistry, College of Horticulture, \\ Bengaluru-05, India \\ ${ }^{2}$ Department of Soil Science and Agricultural Chemistry, College of Horticulture, Bidar-01, \\ University of Horticulture Sciences Bagalkot-04, Karnataka, India
}

*Corresponding author

\section{A B S T R A C T}

\begin{tabular}{|l|}
\hline Ke y w o r d s \\
Micro-watershed, \\
$\begin{array}{l}\text { GIS, Soil site } \\
\text { suitability }\end{array}$ \\
\hline Article Info \\
\hline $\begin{array}{l}\text { Accepted: } \\
\text { 17 March } 2019 \\
\text { Available Online: } \\
\text { 10 April } 2019\end{array}$ \\
\hline
\end{tabular}

\begin{abstract}
A study was undertaken to evaluate eight soil series belonging to Kabirabad 2 microwatershed in Bidar district in Northern Eastern Transition Zone of Karnataka State for sustainable land use planning. Seven soil series were tentatively identified and mapped into eight mapping units using GIS technique. These mapping units were grouped into land capability class II and VI with limitations of erosion, drainage and physico-chemical properties. Soil-site suitability evaluation lowland and midland were moderately suitable (S2) for cultivation of field crops like sorghum, red gram, green gram, bengal gram, black gram and soybean with moderate limitations of drainage and fertility while upland area were marginally suitable (S3) for cultivation of these crops. Whereas, horticulture crops like mango, guava, sapota, custard apple and lime were not suitable $(\mathrm{N})$ in upland because of sever limitation of depth, whereas, in low land and mid land these crops were moderately suitable (S2) with moderate limitations of rooting depth and texture.
\end{abstract}

\section{Introduction}

Food security, environment protection and prosperity of the people depend greatly on sustainable management of soil resources. Estimated degraded land in the country is around 44\% (Mythili and Goedecke, 2015) this is alarming. Soil/land degradation has become major problem across the country and needs proper evaluation for its suitability to various agricultural and allied practices. Improper use of soil resources without suitable management leads to its degradation echoing the concern of planners, researchers and farmers' alike (Bhattacharyya et al., 2015). Therefore it is very much essential to enhance the productivity of soil to meet the future demand of burgeoning population. Soil resource inventory through characterization and soil classification provides detailed information on soil and its related properties. In the recent past, concept of watershed based holistic development has emerged as one of the potential approaches (Sharda, 2011) in rainfed areas which could lead to higher productivity and sustainability in agricultural 
production. Keeping these considerations in view present study was undertaken to evaluate land for its suitability for various purposes such as cultivation of agricultural and horticultural crops in the Kabirabad 2 micro-watershed (MWS) of Northern Eastern Transition Zone (Zone-I) of Karnataka.

\section{Materials and Methods}

Kabirabad 2 MWS covering an area of 560.73 ha situated at $17^{0} 51$ East longitude and $77^{0} 9$ North latitude in Bidar district in Northern Eastern Transition Zone (Zone-I) of Karnataka state with elevation ranging from 520 to $588 \mathrm{~m}$ above mean sea level (MSL). The annual mean maximum and minimum temperature were $30.32{ }^{0} \mathrm{C}$ and $18.93^{\circ} \mathrm{C}$ respectively. The average annual rainfall and relative humidity were $827.93 \mathrm{~mm}$ and $69.4 \%$, respectively. It is well distributed with south-west monsoon (June to October). Acacia (Acacia auruculiformis) and neem (Azadirachta indica) are the predominant trees in the area. The soils are derived from Basaltic origin.

The detailed soil survey was carried out using IRS and Cartosat-1 (2.5 spatial resolution) + LISS-IV (5.8 Spatial resolution) at the scale of 1:8,000 and Toposheet of 1:50,000 from Survey of India (SOI). The pedons were exposed and studied for their morphological properties following the procedure outlined (Soil Survey Staff, 1999). The physicochemical properties (horizon-wise) were estimated following standard procedures. Seven soil series were tentatively identified in the study area and mapped into eight mapping units as phases of soil series (Fig. 1 and Table 1). Weighted mean of each property was calculated and soil-site characteristics of different soil units were obtained as shown in Table 2. These weighted average data have been used to evaluate the land capability classification and soil-site suitability. Land capability map and soil-site suitability maps were prepared using Arc view 3.2a GIS software.

\section{Results and Discussion}

\section{Land capability classification (LCC)}

Soil site characteristics of soil units are given in Table 2 and are matched with the criteria for land capability classification (LCC). The land capability classification of mapping units and their extent in watershed is presented in Figure 2.

Among various series classified soils of Devgir series DGRmB2g1, KGNmB2, MNLiB2g1, MTNiB2g1, RPLiB2g1, RPLmB2 and UDHiB2g2 series are comparatively good and classified into LCC II with limitations of moderate erosion due to class B slope. LINiD3g2 classified into LCC IV with limitations of slope (D class) causing severe erosion (e3 class). Major proportion of the area belongs to class IIse followed by VIse, similar class characteristics with comparable limitations were observed by Sharma et al., (2004) in cultivated soils of Neogal watershed in North-West Himalayas.

\section{Soil-site suitability evaluation for crops}

\section{Horticultural crops}

Soil site suitability criteria for major horticultural crops like guava, custard apple, mango, cashew nut and sapota that are grown in North Karnataka region were prepared. Soil depth, slope and soil $\mathrm{pH}$ are major factors to be considered for recommendation and cultivation horticultural crops. Among the different series of the watershed, most of the area was not suitable for growing of mango. DGR, MNL and MTN series were highly suitable (S1) and UDH series was moderately suitable (S2) for growing mango. Whereas, 
KGN, RPL, LIN series were not suitable $(\mathrm{N})$ for growing mango due to shallow depth, texture and $\mathrm{CaCO}_{3}$ limitations (Fig. 3). Manojkumar (2011) reported that severe limitation of depth, moderate limitations of slope, drainage, depth were the major soil site characteristics influencing the growth and productivity of the mango in soils of the Bastwad micro-watershed of Karnataka were marginally to unsuitable for mango cultivation.

Table.1 Soil series, mapping units and area covered in Kabirabad-2 micro-watershed (MWS)

\begin{tabular}{|l|c|c|}
\hline \multicolumn{1}{|c|}{ Soil Series } & Mapping unit & Area covered (ha) \\
\hline Devgiri series & DGRmB2g1 & $\mathbf{1 4 . 4 2}$ \\
\hline Koudagoan series & KGNmB2 & $\mathbf{1 3 5 . 5 0}$ \\
\hline Lingi series & LINiD3g2 & $\mathbf{1 1 0 . 5 9}$ \\
\hline Mudhnal series & MNLiB2g1 & $\mathbf{6 0 . 1 3}$ \\
\hline Muthangi series & MTNiB2g1 & $\mathbf{4 1 . 0 2}$ \\
\hline Udhawa series & UDHmB2g1 & $\mathbf{5 1 . 1 8}$ \\
\hline Raipalli series & RPLmB2 & $\mathbf{1 1 2 . 9 4}$ \\
\hline
\end{tabular}

Table.2 Land capability classification of Kabirabad-2 MWS

\begin{tabular}{|l|c|c|}
\hline \multicolumn{1}{|c|}{ Soil Series } & $\begin{array}{c}\text { Land capability sub } \\
\text { class }\end{array}$ & Area covered (ha) \\
\hline Devgiri series & IIse & $\mathbf{1 4 . 4 2}$ \\
\hline Koudagoan series & IIse & 135.50 \\
\hline Lingi series & IVse & 110.59 \\
\hline Mudhnal series & IIse & $\mathbf{6 0 . 1 3}$ \\
\hline Muthangi series & IIse & $\mathbf{4 1 . 0 2}$ \\
\hline Udhawa series & IIse & $\mathbf{5 1 . 1 8}$ \\
\hline Raipalli series & IIwe & $\mathbf{1 1 2 . 9 4}$ \\
\hline
\end{tabular}

Fig.1 Soil mapping units of Kabirabad-2 micro-watershed (MWS)

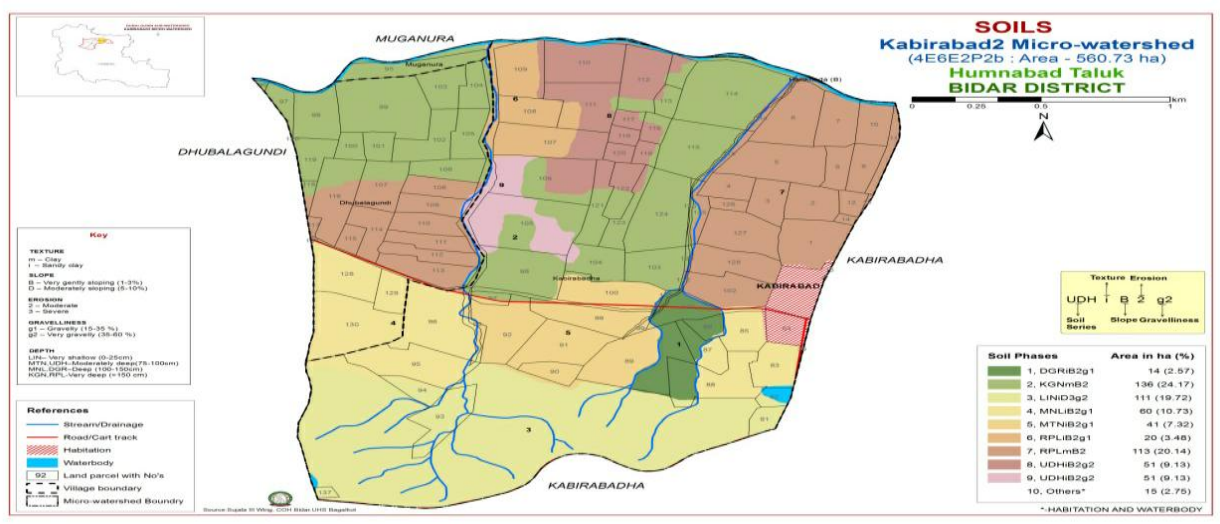


Fig.2 Land capability classification of Kabirabad-2 MWS

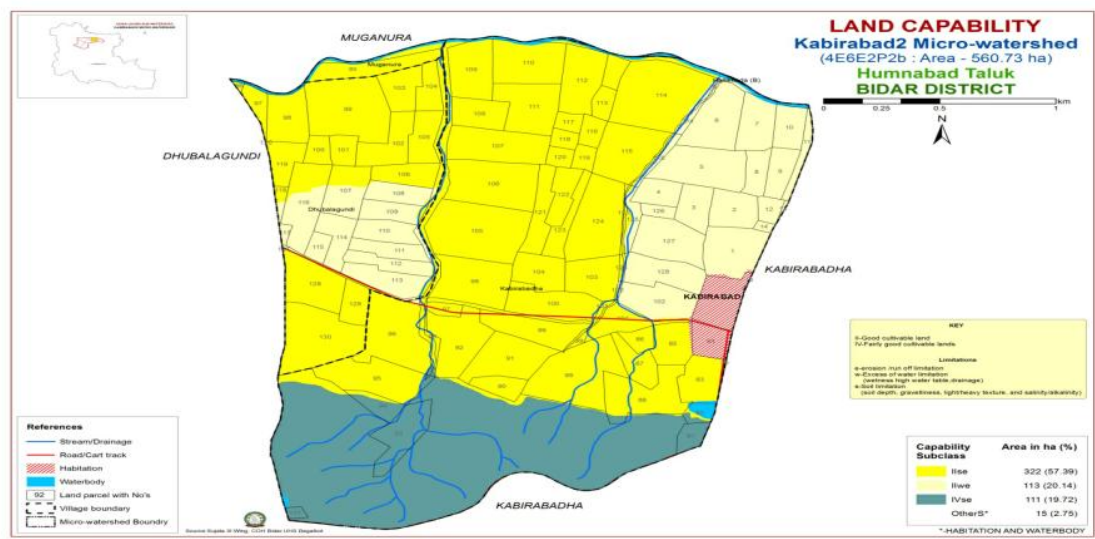

Fig.3 Crop suitability for (a) Red gram (b) Bengal gram (c) Soyabean and (d) Sorghum in Kabirabad-2 MWS
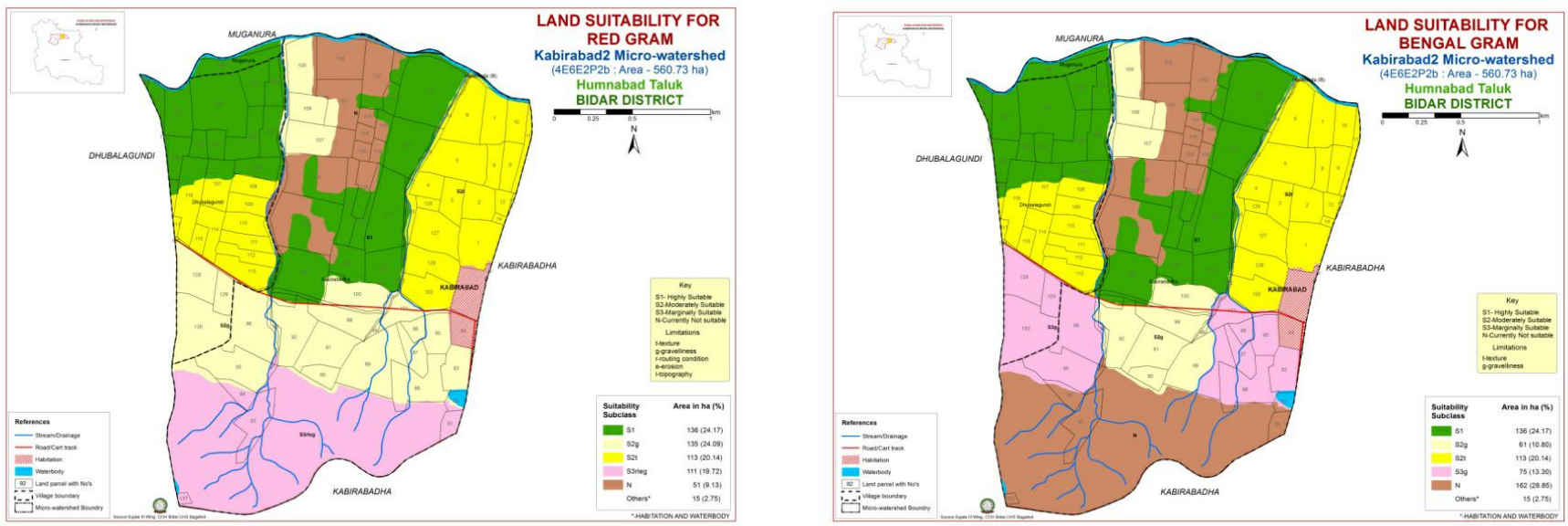

A. Red gram

B. Bengal gram
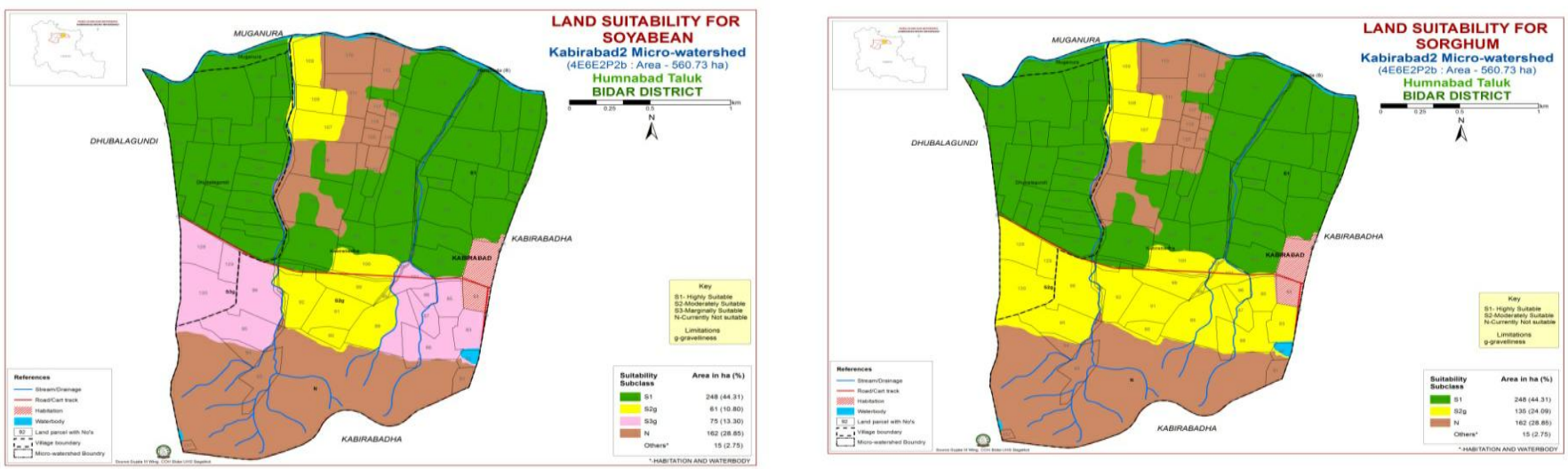


\section{Soyabean}

Fig.4 Crop suitability for (a) Mango

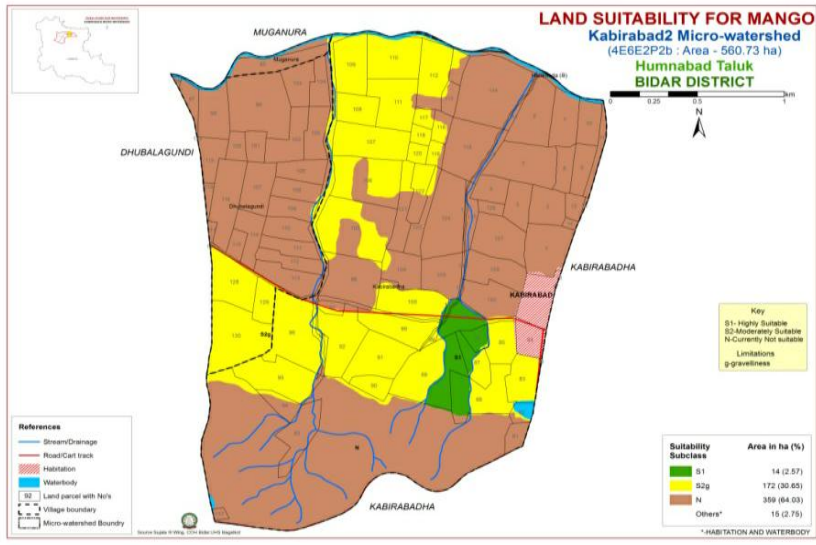

A. Mango

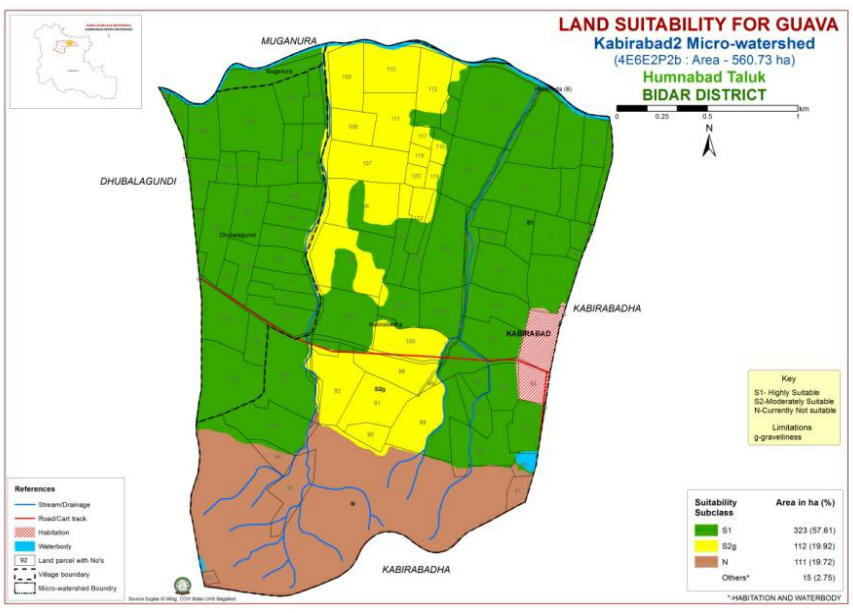

C. Guava

DGR, MNL, KGN and RPL were found highly suitable (S1) for sapota cultivation with no limitations. LIN series was not $(\mathrm{N})$ suitable for sapota cultivation due to shallow depth and texture limitations. Similar observation was made by Amar et al., (2015) in Singhanhalli-Bogur micro-watershed of Karnataka. Similarly guava and cashew nut are moderately suitable to this area.

\section{Field crops}

The optimum requirements of a crop are always region specific. Climate and soil-site parameters play significant role in

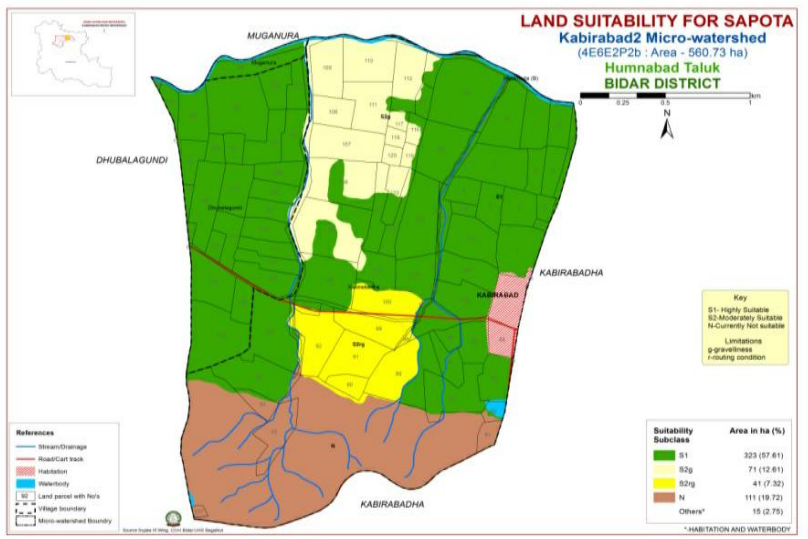

B. Sapota

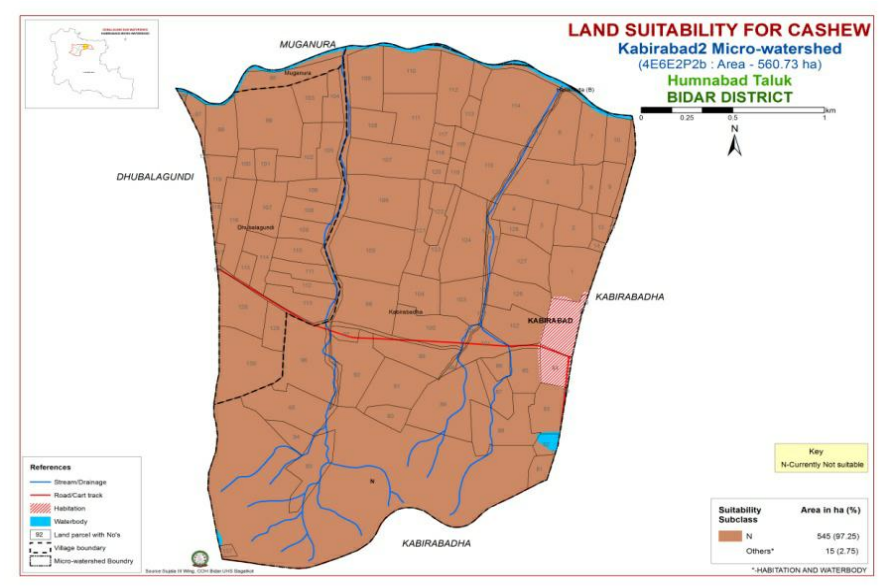

D. Cashew nut

maximizing the crop yields. The kind and degree of limitations were evaluated and soil properties from the study area were matched with soil site suitability criteria (Sehgal, 1996) for various field crops (Table 4) and horticultural crops (Table 5) of the region.

Redgram is long duration pulse crop with deep root system. Hence, soils having very deep depth and texture with high clay content are suitable. All the soils had severe limitations for climate. Among various series MTN, UDH and KGN series were highly suitable (S1) for pigeonpea cultivation with no limitations. MNL and RPL series were 
moderately suitable (S2) and LIN series not suitable $(\mathrm{N})$ for pigeonpea cultivation due to shallow depth and texture limitations. Similar work was also carried out by Gabhane et al., (2006) in Maharashtra, Satyavathi and Suryanarayana (2003) in soils of Telangana.

Similarly MTN, UDH and KGN series were highly suitable (S1) for pigeonpea cultivation with no limitations. MNL and RPL series were moderately suitable (S2) and LIN series not suitable $(\mathrm{N})$ for pigeonpea cultivation due to shallow depth and texture limitations. Similar results reported in Satyavathi and Suryanarayana (2003) in soils of Telangana and Reddy et al., (2014) in Nalgonda district of Andhra Pradesh.

Black gram requires relatively less soil depth and rainfall compared to other deep rooted crops. Large area watershed was moderately suitable (S2) for the crop. Sorghum mainly grown in the rabi season which requires less amount of rainfall and also moderately deep rooted. Some of an area is under not suitable (N) and moderately suitable (S2) due to the limitations of slope, erosion and physicochemical properties Wadodkar et al., (1996) (Fig. 3e and Fig. 4).

It is concluded that, in Kabirabad-2 microwatershed, MTN, UDH, KGN and RPL series have good morphological (moderate erosion, good depth, structure and consistency) and physical (lower Bulk Density and Particle Density, higher porosity and maximum water holding capacity) characteristics. Similarly they had high to medium OC, N, P, K, S, Ca and $\mathrm{Mg}$ compared to other mapping units. Because of these favorable properties most of the crops such as red gram, sorghum, black gram, bengal gram, green gram, soybean, sapota, mango, guava, cashew nut and custard apple etc. are highly suitable with minimum management practices. These mapping units are classified under land capability class II with few limitations (fertility, climate \& drainage). Whereas, LIN series having limitations of shallow soil depth accompanied with steep slope limit suitability of any crop in that matter. Hence, require immediate attention with regard to their management through certain suitable soil and water conservation interventions to upgrade these soils to higher land capability class.

\section{References}

Amar, D. M. K., Massaquoi, S. D. A. and Parameshgouda, L. P., 2015, Land evaluation in Singhanhalli-Bogur micro-watershed in Dharwad district of Northern Transition Zone of Karnataka, India through remote sensing and geographical information systems. Int. J. Agric. Sci. Res., 4(6): 171-184.

Bhattacharyya, R., Ghosh, B. N., Mishra, P. K., Mandal, B., Srinivasa Rao, Ch., Sarkar, D., Das, K., Anil, K. S., Lalitha, M., Hati, K. M. and Franzluebbers, A. J., 2015, Soil Degradation in India: Challenges and Potential Solutions. Sustainability, 7: 3528-3570.

Gabhane, V. V., Jadhao, V. O. and Nagdeve, M. B., 2006, Land evaluation for land use planning of a macro-watershed in Vidarbha region of Maharashtra. J. Indian Soc. Soil Sci., 54 (3): 307-315.

Manojkumar, D., 2011, Characterization and classification of soils of a microwatershed on basalt parent rock in northern transition zone of Karnataka. M. Sc. (Agri.) Thesis, Univ. Agric. Sci., Dharwad, Karnataka, India.

Mythili, G. and Goedecke, J. 2015, Economics of Land Degradation in India. In: Economics of Land Degradation and Improvement - A Global Assessment for Sustainable Development. pp. 431-469. 
Reddy, K. G., Goverdhan, V. and Sathish Kumar, Y. S, 2014, Soil-site suitability evaluation for commonly growing crops of Nalgonda district Andhra Pradesh. Ann. Plant., Soil Res., 16 (1): 68-71.

Satyavathi P. L. A. and Suryanarayana, M, R., 2003, Characterization and classification of shallow, medium and deep red and black soil of Northern Telangana Zone in Andhra Pradesh $J$. Tropical Agric., 41: 23-29.

Sehgal, J. L., 1996, Pedology: Concepts and Application, Kalyani Publishers, New Delhi.

Sharda, V. N., 2011, Land degradation and watershed management issues in Himalayan region: Status and Strategies. In Workshop on "Mountain Agriculture in Himalayan Region: Status, Constraints and Potential";
ICAR: Dehradun, India. pp. 1-22. Sharma, V. K., Sharma, P. D., Sharma, S. P., Acharya, C. L. and Sood, R. K., 2004, Characterization of cultivated soils of Neogal watershed in North-West Himalayas and their Suitability for major crops. J. Indian Soc. Soil Sci., 52 (1): 63-68.

Soil Survey Staff. Soil Taxonomy - A basic system of soil classification for making and interpreting soil surveys. Second edition. Agricultural Hand Book No. 436, United States Department of Agriculture, Washington, D. C., USA, 1999.

Wadodkar, M. R., Sehgal, J. L. and Challo, O., 1996, Soil-site suitability for soybean in Vidarbha region. Agropedology, 6: 95-101.

\section{How to cite this article:}

Manjunath, N.V., Ashok S. Alur, B.V. Shreenivas, P.K. Naikodi and Shivanna, M. 2019. Land Evaluation of Kabirabad 2 Micro-Watershed in Northern Eastern Transition Zone of Karnataka, India. Int.J.Curr.Microbiol.App.Sci. 8(04): 2590-2596.

doi: https://doi.org/10.20546/ijcmas.2019.804.301 